\title{
The Impact of Oil Price on Economic Development of Kurdistan Region of Iraq for Time Period (1997-2019)
}

\author{
Dr. Hozan Nayyef Abdulqader
}

Department of Economics, College of Economics and Administration, Salahaddin University, Erbil-Kurdistan

Received: 03 May 2021; Received in revised form: 06 Jun 2021; Accepted: 12 Jun 2021; Available online: 23 Jun 2021

\begin{abstract}
Kurdistan region of Iraq signifies a great case study to investigate the impact of oil price, for the reason that most of its producing reliance on exporting crude oil KRG is one of the main oil exporting regions. Usually, the national revenue relies on crude oil revenue in KRG comprises a great percentage of Kurdistan region of Iraqi government's budget and also KRG's economy can be impact by would economic during economic difficulties. Consequently, growing oil crude oil price can influence on economic development in Kurdistan region of Iraq. Therefore, it is important to utilize other resource instead of oil income as a different approach to increase region's income. The key objective of this article is to investigate the impacts of oil price and oil production value on economic development. Annual growth rate, compound growth rate and correlation coefficient can be utilized to estimate of the data. The findings revealed that an economic development is one of the most significant sources of economic transformation since it reproduces the society's capability to rise productive volume and ideal investment and likewise sustainability obligation comprises an expanded economy on the face of shocks, dynamically implements technology and head accumulation human money, competitively can increase comparative advantages compared to the other. Consequently, it operates within steady, balanced economic strategies and economic growth and there was positively statistically significance between oil price and GDP, oil production value and GDP.
\end{abstract}

Keywords-Oil Price, Economic Development, Oil Demand, Oil Supply, KRG.

\section{INTRODUCTION}

The expanding of the unrefined petroleum cost as of late was truly taken in consider. Anyway oil was viewed as an auxiliary source, it turned into a critical asset in the social orders later. In the most recent decade, the Middle east nations are shakiness in monetary turn of events, nonetheless, of late, nations understood the expanding the oil items and boosting of its cost improved the oil nation makers. Afterward, the vast majority of the Middle east nations experienced the falling of oil cost and financial development including Kurdistan locale of Iraq Kurdistan area of Iraq has been considered as one of those nations that has instable relations with monetary development and financial turn of events. In spite of these, it had an adequate financial development in the previous decades (Mo, et al 2019). The essentialness of this article is uncovering the effect of raw petroleum cost on financial development and social occasion information was utilized to look at that sway Kurdistan area of Iraq as a rule is the spot of viable aspect of the exploration. It consolidated these stray pieces, predefining oil cost and parceling oil objections and stacking and exhausting oil barrels. At the end of the WWII and in the wake of disintegrating of European economy, these associations expected command over some wide smooth zone in the Middle East. There were some valuable inspirations to make this basic for them including the closeness of the zone to Europe and oil exhausting. Seven controlling framework associations were built up; five of the American and the other two were British and Dutch. They were known as the seven sisters and they devoured the oil market and predefined the expense of oil as they required (Nyangarika, et al 2019). The oil cost has created since the business disclosure of the oil market It was toward the start of disclosure that was resolved at the oil wells. Under a

This article can be downloaded from here: www.ijaems.com 
"syndication of a couple," the oil market won. It was then decided in the ports where the oil business was found and extended in numerous nations. This is because of the imposing business model of a couple of oil market organizations that tried to augment their benefits, and afterward form into a serious value subject to request and flexibly factors. This is the section of a few oil creating nations to the oil market (Chen, et al 2020). The idea of monetary development contrasts as indicated by the various scholars and the masters and the circumstances experienced by the nations or people groups. More consideration was paid to the financial development of the industrialized nations, which rose with the mechanical unrest in Europe. Monetary development implies the unconstrained financial extension, which doesn't need change in the monetary structure of the general public and it is estimated by monetary units, for example, public salary, however after the finish of World War II, the world was isolated into created and in reverse nations (Gazdar, et al 2019).

\section{STATEMENT OF THE PROBLEM}

Kurdistan area of Iraq is one of the significant oil trading nations. By and large, the public pay relies upon unrefined petroleum. Oil income in Kurdistan region of Iraq covers an extraordinary percent of Kurdistan area of Iraqi government's economic plan. Accordingly, Kurdistan district of Iraqi economy could be impact by would monetary during economic issues. In this manner, expanding oil raw petroleum cost can impact on economic development in Kurdistan region of Iraq. So it is vital to utilize other asset rather than oil income as another methodology to increase public income. Past monetary scientists don't address this issue in their investigation, hence, the specialist have picked this subject so as to discover the connection between raw petroleum cost and economic development.

\section{SIGNIFICANCE OF THEI STUDYI}

The ongoing stun of oil price

on the planet is brought a dubious discussion among strategy producers and scholastics. Accordingly, it is influenced on worldwide creation, and economic development. Kurdistan region of Iraq speaks to a decent contextual investigation to analyze the impact of oil price, in light of the fact that the vast majority of its procuring reliance on trading raw petroleum. In this way, the huge of the examination is to contributing hypothetical sides and zeroing in on oil prices and monetary development in order to comprehend the significant of oil price and the effect any adjustment in oil price on This article can be downloaded from here: www.ijaems.com sending out oil nations, for example, Kurdistan region of Iraq. Consequently, the discoveries of this examination are advantageous to the administration, economic strategy producers, the private part and scholastics.

\section{RESEARCH OBJECTIVES}

The followings are the main research objectives:

Research Objective 1: To recognize the influence elements of crude oil price on economic development in Kurdistan region of Iraq.

Research Objective 2: To find the relationship between crude oil price and economic development in Kurdistan region of Iraq.

Research Objective 3: To recognize the influence of change oil price on economic development in Kurdistan region of Iraq.

\section{Research Questions}

The followings are the main research questions:

Research Question 1: What is the effect of crude oil price on economic growth in Kirkuk?

Research Question 2: What is the scale and direction of crude oil price on economic development?

Research Question 3: What is oil price and economic development?

\section{Literature Review}

Jarrett, et al (2019), recognized changes of oil costs affect the veritable GDP on all G7 economies. In any case, there is a drawn out unprejudiced nature of the oil influence in specific nations while the oil influence is imperative of the remainder of the G7 economies. Similarly they show that unmistakable administrative approaches have assisted with decreasing the effect of oil costs in the business zone.

Lee \& Lee, (2019) endeavored to take a gander at the effect from oil cost and oil use changes on nuclear essentialness advancement on account of worldwide crude oil esteem climbs and oil smoothly decline. Moreover, Wen, et al (2019) zeroed in on the G7 nations in their assessment, Norway and the Euro-locale. The showed rising oil cost by and large essentially impact GDP improvement than that of oil regard fall with the last being quantifiably in extraordinary in all nations ap. In passing on nations such Norway, thing improvement answers intensely to an expansion in the oil cost changing and in Britain the thing progression is unexpectedly unfairly affected taking into account all the more sharp confirmed change standard appreciation. 
Chen, et al (2020), in various nations exogenous oil agilely obstructions cause in any event a brief deny in genuine wages, and bringing down of the near to money against the dollar and an augmentation in transient credit costs. Despite theoretical similitudes, there is solid quantifiable guide that the restriction to exogenous oil deftly impedances changes across $\mathrm{G} 7$ nations.

The clarification behind Katırcioglu, et al (2020) study was to assess the brisk impact of oil costs on macroeconomic focuses and confirming the public banks of the G7 have reacted to exogenous oil regard stuns. The outcome shows concerning the reaction of monetary arrangement, the public banks of a large portion of the nations responded to the oil regard surprise by making credit expenses and diminishing genuine cash changes at last, an imperative aspect of the impacts of the oil costs stumble to fulfillment in truly from the reaction of money related philosophy.

In another paper, Lin, (2020), analyzed the relationship between the strategy in the oil market and a business cycle for G7 nations. The paper fixed that models with exogenous oil factors by and large beat the looking at univariate assurance which bars oil from the examination. Likewise the capacity of oil shocks in slumps has brought down after some time and overhauls in essentialness limit and the methodology by financial masters are the once that chosen the impacts of oil dazes. The reverse way around the economies of the G7 countries can not impact oil financial circumstances.

Shahbaz, et al (2017), assess the impact of oil costs in a couple of European countries using data. As a matter of fact, rising oil costs lead to obstruct supreme financial development by more than dropping oil costs animated.

You, et al (2017), are examining the association between oil costs and external alters, especially the effects of oil solicitation and oil nimbly paralyzes on outside equalities of oil conveying and oil getting countries. Likewise, Nwanna \& Eyedayi, (2016) among their assessment endeavored to realize how much oil esteem staggers sway improvement in different countries with the assistance of new trade. The assessment shows that oil value increases have an unadulterated and helpful result on the oil exporters GDP improvement despite the way that this positive direct effect is moderate by a negative however minimal meandering effect.

Jianwei, et al (2017), separated the co-joining association between overall financial movement and crude oil real expenses. The paper showed that oil costs are influence on a very basic level by changes in the Kilian financial record through since a long time back run balance situation and short-run impacts. The alteration pattern of crude oil costs due to a consistent change in the Kilian monetary record takes a colossal time than that achieved by an unending change in the US dollar list. The examination of Aimer, (2016) shows that differing oil market content paralyzes have the critical effect in portraying the adjustments in protections trade returns. The volume of the effects of the fundamental shocks is small provoking an assumption that other control factors, for instance, exchange rates, advantage rates and purchaser intense spending have all the earmarks of being coherent determinants of protections trade returns.

\section{THE CONCEPT OF THE PRICE OF OIL}

The oil price is characterized as "the estimation of the substance or the oil based commodity communicated in real money" (Okere \& Ndubuisi, 2017) during a particular timeframe and affected by a scope of financial, social, political and climatic components and so on. The oil cost has made since the business disclosure of the oil market. It was at the beginning of revelation that was settled at the oil wells. Under a "controlling framework of a couple," the oil market won. It was then chosen in the ports where the oil business was found and stretched out in various countries. This is a direct result of the partnership of two or three oil market associations that hoped to extend their advantages, and thereafter structure into a genuine worth subject to ask for and deftly factors. This is the entry of a couple of oil conveying countries to the oil market (Dudian, et al 2017). This improvement in cost or how to choose it shows that the expense of oil has a couple of sorts or terms that will be referred to according to the advancement of great importance of the ascent of such these animal categories, and the standard utilized in the evaluation of oil. Besides, the norm on which the oil item is surveyed, is the money related worth or the money picture of a barrel of raw petroleum surveyed in US dollars of 42 gallons passed on in the US monetary unit for instance \$100/barrel and that this cost is dependent upon unsurprising insecurities as a result of the chance of the market. International oil, which is portrayed by dynamism and instability, which has been reflected in oil expenses and make them temperamental costs and subject to predictable changes until the marvel of shakiness has become a zeroing in on wonder (Zhao, et al 2018).

\section{The Concept of Economic Growth}

The idea of economic development varies as per the various scholars and the authorities and the circumstances experienced by the nations or people groups. More consideration was paid to the monetary development of the industrialized nations, which rose with the modern insurgency in Europe ( $\mathrm{Li}$, et al 2017). Economic development implies the unconstrained monetary 
extension, which doesn't need change in the economic development of the general public and it is estimated by monetary units, for example, public salary, however after the finish of WWII, the world was secluded into made and in invert countries. More thought is paid to progress than to advancement, which infers the proposed financial augmentation, which can simply happen with the intercession of the state, which requires the need to change the monetary turn of events (Al-Sasi, et al 2017).

\section{METHOD}

The key goal of this article is to evaluate the effects of unrefined petroleum value, oil creation esteem on monetary development in Kurdistan area of Iraq. The information is yearly information which were uniting a period from 1997-2019. The perception were 21 which can be sufficient to utilize relationship coefficient and furthermore yearly development rate used to control the boosting or diminishing the year partner to prior year and compound development rate used to decide the pace of boosting or decreasing of the timeframe and furthermore near apply to direct the pace of boosting or lessening the year contrasting with the base year.

\section{Research Design}

The association between oil creation esteem, oil cost, and financial improvement are inspected in the plan of flow research in Kurdistan area of Iraq. Furthermore, the plan investigative examination could be made in this exploration as it sought after to decide the associations among components and the examination factors. The plan was more noteworthy as it encountered one kind of information were given information and data from the yearly information during 1997-2019.

\section{Research Hypotheses}

The followings are the main research hypotheses:

Research hypothesis 1: There is a positive and significant association between GDP and oil price.

Research hypothesis 2: There is no a positive and significant association between GDP and oil price.

Research hypothesis 3: There is no a positive and significant association between GDP and the value of oil production.
Research hypothesis 4: There is a positive and significant association between GDP and the value of oil production.

\section{RESULTS}

The outcomes from this study demonstrated that financial advancement is one of the most critical wellsprings of monetary change since it duplicates the populace's capacity to help profitable volume and ideal speculation and furthermore manageability commitment involves an extended economy on the essence of stuns, powerfully embraces innovation and head amassing human cash, seriously can increase relative preferences contrasted with the different. Thus, It works inside steady, stable financial strategies and monetary turn of events and there were emphatically measurably centrality between oil cost and GDP, oil creation worth and GDP. This indicates that boosting a percentage of the value of oil production and oil price in Kurdistan, GDP upsurges also. According to (Rui, et al 2018) ,Oil price have a significant infleunce on the GDP through its influence and involvement to government incomes. Worldwide and locally, the oil prices is variations among the international considerations and it is occurring from worldwide actions In this point, if the oil price improved, it promotes oil exporting economic and harm oil importing economics.

\section{Oil Price}

The oil cost is a cash related worth or a monetary picture which is per barrel of crude oil in the US dollar and it is conveyed in genuine cash since it is associated with US dollar and can be introduced to oil cost in the oil market inside the thoughts of various things, for instance, (the cost achieved, the cost articulated, the obligation rate and the expense of sign) (Maji, et al 2017). Table (1) demonstrates the time of (1997 2019) were taken so as to show change of oil cost in those period saw numerous monetary turns of events, political and military reflected in the entire of the truth of the oil market then as oil cost tumbled from (16 75\$) in 1997 and it expanded by 0202 in $1998 \quad(2023 \$)$, the ascents proceeded in 1997 by $0114 \quad(18$ 81\$) at that point the cost of oil in 1998 diminished by 0267 (12 21\$) Besides, after 1998, the cost of oil expanded when 1997 were as a base year The cost of oil expanded a ton in 2012 (109 33) Besides, the ascent of oil price proceeded until 2013 then it diminished because of numerous reasons: 
- The ascend in oil price has contributed altogether to the consolation of nations.

The decrease in worldwide monetary development rates has prompted a decrease worldwide utilization of unrefined petroleum, just as political variables and others contributed somehow to the decrease in oil price.
- In general, the marvel of hypothesis which is presented to the oil business.

By auditing chronicled advancements in oil price it very well may be reasoned that Oil price have been dependent upon numerous changes because of elements that cover Economic, political, military and other.

Table 1- Oil Price

\begin{tabular}{|c|c|c|}
\hline Years & $\begin{array}{ll}\text { Oil } & \text { price }\end{array}$ & $1997 /$ year \\
\hline 1997 & 1675 & - \\
\hline 1998 & $20 \quad 23$ & $\begin{array}{ll}0 & 202\end{array}$ \\
\hline 1999 & $\begin{array}{ll}18 & 81\end{array}$ & $\begin{array}{ll}0 & 117\end{array}$ \\
\hline 2000 & $\begin{array}{ll}12 & 21\end{array}$ & $\begin{array}{ll}-0 & 269\end{array}$ \\
\hline 2001 & 1742 & $\begin{array}{ll}0 & 032\end{array}$ \\
\hline 2002 & $27 \quad 4$ & $\begin{array}{ll}0 & 631\end{array}$ \\
\hline 2003 & 2308 & $\begin{array}{ll}0 & 368\end{array}$ \\
\hline 2004 & $24 \quad 34$ & $\begin{array}{ll}0 & 441\end{array}$ \\
\hline 2005 & $\begin{array}{ll}28 & 08\end{array}$ & $\begin{array}{ll}0 & 661\end{array}$ \\
\hline 2006 & $\begin{array}{ll}36 & 02\end{array}$ & $\begin{array}{ll}1 & 133\end{array}$ \\
\hline 2007 & $\begin{array}{ll}50 & 51\end{array}$ & $\begin{array}{ll}198 \\
\end{array}$ \\
\hline 2008 & $\begin{array}{ll}60 & 58\end{array}$ & $\begin{array}{ll}2 & 621\end{array}$ \\
\hline 2009 & 696 & $\begin{array}{ll}3 & 078\end{array}$ \\
\hline 2010 & $\begin{array}{ll}93 & 98\end{array}$ & $4 \quad 47$ \\
\hline 2009 & $\begin{array}{ll}60 & 81\end{array}$ & 2599 \\
\hline 2010 & $\begin{array}{ll}77 & 31\end{array}$ & $\begin{array}{ll}3 & 581\end{array}$ \\
\hline 2011 & $\begin{array}{ll}107 & 39\end{array}$ & $\begin{array}{ll}5 & 367\end{array}$ \\
\hline 2012 & 10933 & $\begin{array}{ll}5 & 487\end{array}$ \\
\hline 2013 & 10573 & $\begin{array}{ll}5 & 275\end{array}$ \\
\hline 2014 & $\begin{array}{ll}96 & 27\end{array}$ & $\begin{array}{ll}4707 \\
\end{array}$ \\
\hline 2015 & $\begin{array}{ll}49 & 47\end{array}$ & $\begin{array}{ll}1931 \\
\end{array}$ \\
\hline 2016 & $\begin{array}{ll}40 & 61\end{array}$ & $\begin{array}{ll}1408 \\
\end{array}$ \\
\hline 2017 & 5249 & 2108 \\
\hline
\end{tabular}

Table (2) exhibits the oil approached to (20 21) dollar and the yearly development rate were positive expanded by $(2029 \%)$ in 1997. In (1997, 1998), the oil cost were $(1879,12$ 31) dollar individually and the yearly development rate were negative rising to (- $698 \%,-3481 \%)$ separately. In (1999, 2000), the oil cost were (17 39, 27 59) dollar separately and the yearly development rate were positive rising to $(4159 \%, 58$ 19\%) individually also, the yearly development rate become negative outcome in 
2001 however after 2001 the yearly development rate were positive rate until 2009. The yearly development rate were negative in 2009 which were $(-35$ 28\%) at that point In $(2010,2011,2012)$, the oil cost were (77 31, 107 39, 109 38) dollar individually and the yearly development rate were positive rising to $(2708 \%, 3881 \%, 182 \%)$ separately. Finally, the yearly development rate were positive outcome in 2017 The yearly compound rate for the arrangement years were $005 \%$.

Table 2- Annual compound growth and growth for oil production

\begin{tabular}{|c|c|c|c|}
\hline Years & Oil Price & $\begin{array}{c}\text { Annual Growth } \\
\text { Rate }\end{array}$ & $\begin{array}{c}\text { Annual Compound } \\
\text { Growth } \quad \text { Rate }\end{array}$ \\
\hline 1997 & 1686 & - & \multirow{23}{*}{$0 \quad 05 \%$} \\
\hline 1998 & $20 \quad 21$ & $2034 \%$ & \\
\hline 1999 & 1879 & $-7 \quad 04 \%$ & \\
\hline 2000 & 1231 & $-3488 \%$ & \\
\hline 2001 & $17 \quad 39$ & $42 \quad 01 \%$ & \\
\hline 2002 & $27 \quad 59$ & $58 \quad 25 \%$ & \\
\hline 2003 & $23 \quad 12$ & $-1623 \%$ & \\
\hline 2004 & $24 \quad 36$ & $536 \%$ & \\
\hline 2005 & $\begin{array}{ll}28 & 1\end{array}$ & $1535 \%$ & \\
\hline 2006 & $36 \quad 05$ & $28 \quad 29 \%$ & \\
\hline 2007 & $50 \quad 59$ & $40 \quad 33 \%$ & \\
\hline 2008 & 61 & $2057 \%$ & \\
\hline 2009 & $\begin{array}{ll}69 & 04\end{array}$ & $1318 \%$ & \\
\hline 2010 & $\begin{array}{ll}94 & 1\end{array}$ & $36 \quad 29 \%$ & \\
\hline 2011 & $60 \quad 86$ & $-3532 \%$ & \\
\hline 2012 & $\begin{array}{ll}77 \quad 31 \\
\end{array}$ & $27 \quad 14 \%$ & \\
\hline 2013 & $107 \quad 39$ & $38 \quad 87 \%$ & \\
\hline 2014 & 10938 & $185 \%$ & \\
\hline 2015 & $105 \quad 87$ & $-3 \quad 27 \%$ & \\
\hline 2016 & $96 \quad 29$ & $-9 \quad 04 \%$ & \\
\hline 2017 & $49 \quad 49$ & $-48 \quad 60 \%$ & \\
\hline 2018 & $40 \quad 68$ & $-1780 \%$ & \\
\hline 2019 & 5251 & $2908 \%$ & \\
\hline
\end{tabular}

\section{Oil Production Value}

Irrefutably, the primary oil fields were found in 1923 (Khana Oil) was for close by use and besides Kurdistan region of Iraq were the ensuing noteworthy oil creator after Iran which began business creation in 1912. Moreover, Kurdistan region of Iraq had a certified creation and huge sums in 1934 The oil creation had been growing to reach (3 7) million barrels for consistently in
1979 while the oil creation became (3 5) million barrels for every day in 1989 because of war and Kurdistan region of Iraq's assault of Kuwait in 1991, oil creation dropped to (278) thousand barrels for consistently. The condition continued until 1996 when the program of swapping oil for food happened. Moreover, the oil creation regard were found by copying the oil creation and oil cost Accordingly, the oil creation regard drew 
nearer to (379) million dollar in 1995 which extended to (764) million dollar and it extended until 2000 (899) million dollar. It lapsed slowly from 2000-2003 yet, in 2003, the oil creation regard lessened distinctly considering war From 2003 to 2009, the oil creation regard extended a lot considering the way that in this period the oil cost and oil creation extended. The best year for oil creation regard were 2012 (978) considering the way that the oil cost become most extraordinary worth diverging from various years by then oil cost become less and less from 2013 to 2016 and the oil creation regard become less and less from this period. At last, the oil creation regard extended a tiny bit at a time in 2017 (5987).

\section{Compound Growth rate and annual Growth ready for} Oil production
Table (3) shows that in $(1997,1998,1999,2000$, 2001,2002, 2003, 2004, 2005, 2006, 2007, 2008, 2009, 2010, 2011, 2012, 2013, 2014, 2015, 2016, 2017, 2018, 2019), the oil creation were (392 838, 779 136, $493943,7022 \quad 93, \quad 13217 \quad 78, \quad 20780$ 04, $16972 \quad 39, \quad 14412 \quad 84, \quad 5591 \quad 9,20292 \quad 55$, $2594761, \quad 33513 \quad 4,41396 \quad 38,63715 \quad 11,42322$ 04, $5339297,848934,97071 \quad 21,92318 \quad 64$, $8841155,5428063,49159 \quad 34$, and 53630 24) separately and the yearly development rate were (98 33\%, 533 96\%, 42 18\%, 88 19\%, 57 $21 \%, \quad-13 \quad 82 \%, \quad-15 \quad 08 \%, \quad-61 \quad 20 \%, \quad 262$ $89 \%, \quad 2786 \%, \quad 2915 \%, \quad 2352 \%, \quad 5391 \%$, $-3357 \%, \quad 2615 \%, \quad 5899 \%, \quad 1434 \%,-4$ $89 \%, \quad-423 \%, \quad-38 \quad 60 \%, \quad-9 \quad 43 \%$, and 9 $09 \%$ ) individually which had positive yearly development rate.

Table 3- Growth rate and Compund growth ratelyear for Oil Production

\begin{tabular}{|c|c|c|c|}
\hline Annual & Oil Production & Growth year/year & $\begin{array}{l}\text { Compound Growth } \\
\text { Rate/year }\end{array}$ \\
\hline 1997 & 392838 & - & \multirow{16}{*}{$0 \quad 20 \%$} \\
\hline 1998 & $779 \quad 136$ & $98 \quad 33 \%$ & \\
\hline 1999 & 493943 & $53396 \%$ & \\
\hline 2000 & 702293 & $42 \quad 18 \%$ & \\
\hline 2001 & $13217 \quad 78$ & $88 \quad 19 \%$ & \\
\hline 2002 & $20780 \quad 04$ & $57 \quad 21 \%$ & \\
\hline 2003 & $16972 \quad 39$ & $-1382 \%$ & \\
\hline 2004 & 1441284 & $-1508 \%$ & \\
\hline 2005 & 55919 & $-6120 \%$ & \\
\hline 2006 & $20292 \quad 55$ & $26289 \%$ & \\
\hline 2007 & $25947 \quad 61$ & $2786 \%$ & \\
\hline 2008 & $33513 \quad 4$ & $2915 \%$ & \\
\hline 2009 & $41396 \quad 38$ & $2352 \%$ & \\
\hline 2010 & $63715 \quad 11$ & $5391 \%$ & \\
\hline 2011 & $42322 \quad 04$ & $-3357 \%$ & \\
\hline 2012 & 5339297 & $26 \quad 15 \%$ & \\
\hline
\end{tabular}




\begin{tabular}{|c|c|c|}
\hline 2013 & $84893 \quad 4$ & $5899 \%$ \\
\hline 2014 & $97071 \quad 21$ & $1434 \%$ \\
\hline 2015 & $92318 \quad 64$ & $-4 \quad 89 \%$ \\
\hline 2016 & 88411 & $-4 \quad 23 \%$ \\
\hline 2017 & 54280 & $-38 \quad 60 \%$ \\
\hline 2018 & 49159 & $-9 \quad 43 \%$ \\
\hline 2019 & 53630 & $9 \quad 09 \%$ \\
\hline
\end{tabular}

\section{GDP}

Table (4) shows that the Gross Domestic Product equaled to (3999 691) million dollar and the annual growth rate were positive increased by $(6384 \%)$ in 1996. In (1997), the Gross Domestic Product were (1027 443) dollar respectively and the annual growth rate were negative equaling to $(-8432 \%)$ respectively. In (2001, 2002, 2003), the Gross Domestic Product were (-18 94\%,-080\%, -36 69) dollar respectively and the annual growth rate were positive In addition, The compound worth rate of Gross Domestic Production were $15 \%$

Table 4- Growth rate and Compund growth ratelyear for GDP

\begin{tabular}{|c|c|c|c|c|}
\hline Annual & GDP & Growth year/year & $\begin{array}{l}\text { Compound } \\
\text { Rate/year }\end{array}$ & Growth \\
\hline 1997 & $3999 \quad 691$ & - & \multirow{19}{*}{$0 \quad 15 \%$} & \\
\hline 1998 & $6553 \quad 351$ & $6384 \%$ & & \\
\hline 1999 & $1027 \quad 443$ & $-84 \quad 32 \%$ & & \\
\hline 2000 & $1058 \quad 458$ & $301 \%$ & & \\
\hline 2001 & $1745 \quad 897$ & $6494 \%$ & & \\
\hline 2002 & $2603 \quad 095$ & $49 \quad 09 \%$ & & \\
\hline 2003 & $2110 \quad 039$ & $-1894 \%$ & & \\
\hline 2004 & 2093007 & $-0 \quad 80 \%$ & & \\
\hline 2005 & $1325 \quad 015$ & $-36 \quad 69 \%$ & & \\
\hline 2006 & $36627 \quad 9$ & $26625 \%$ & & \\
\hline 2007 & $49954 \quad 89$ & $3638 \%$ & & \\
\hline 2008 & $65140 \quad 29$ & $30 \quad 40 \%$ & & \\
\hline 2009 & $88840 \quad 05$ & $3638 \%$ & & \\
\hline 2010 & $131613 \quad 7$ & $48 \quad 14 \%$ & & \\
\hline 2011 & 1116609 & $-15 \quad 16 \%$ & & \\
\hline 2012 & 1385167 & $24 \quad 05 \%$ & & \\
\hline 2013 & $\begin{array}{ll}185749 & 7\end{array}$ & $3409 \%$ & & \\
\hline 2014 & 218001 & $1736 \%$ & & \\
\hline 2015 & $234648 \quad 4$ & $763 \%$ & & \\
\hline
\end{tabular}

This article can be downloaded from here: www.ijaems.com

(C)2021 The Author(s). Published by Infogain Publication.

This work is licensed under a Creative Commons Attribution 4.0 License. http://creativecommons.org/licenses/by/4.0/ 


\begin{tabular}{|l|c|c|}
\hline 2016 & $214648 \quad 4$ & $-8 \quad 52 \%$ \\
\hline 2017 & 1796402 & $-16 \quad 30 \%$ \\
\hline 2018 & 171489 & $-4 \quad 53 \%$ \\
\hline 2019 & $172346 \quad 4$ & $0 \quad 049 \%$ \\
\hline
\end{tabular}

The comparison between the value of oil production and GDP

As we can see in table (5), the correlation among GDP and oil creation esteem which the green line is GDP and blue line is oil creation esteem from 1995 to 2003, the GDP expanded in 1996 contrasting with the aftereffect of GDP in 1995 then after 1996 the GDP expanded or diminished gradually until 2003 however the oil creation expanded from 1995 to 2000 then it diminished until 2003 Moreover, after 2003 the GDP and oil item esteem were changed a similar which implies that when oil creation esteem expanded then the GDP expanded also and that when oil creation esteem diminished then the GDP diminished too

Table 5- Correlation Analysis

\begin{tabular}{|c|c|c|c|c|}
\hline & & GDP & $\begin{array}{c}\text { Oil } \\
\text { price }\end{array}$ & $\begin{array}{l}\text { Oil } \\
\text { Production } \\
\text { Value }\end{array}$ \\
\hline \multirow[t]{3}{*}{ GDP } & \multirow{3}{*}{$\begin{array}{l}\text { Pearson } \\
\text { Correlation } \\
\text { Sig (2-tailed) } \\
\text { N } \\
\end{array}$} & 1 & $831^{* *}$ & $899^{* *}$ \\
\hline & & & 000 & 000 \\
\hline & & 21 & 21 & 21 \\
\hline \multirow[t]{3}{*}{ Oil price } & \multirow{3}{*}{$\begin{array}{l}\text { Pearson } \\
\text { Correlation } \\
\text { Sig (2-tailed) } \\
\text { N }\end{array}$} & $831^{* 8}$ & 1 & $901^{* *}$ \\
\hline & & 000 & & 000 \\
\hline & & 21 & 21 & 21 \\
\hline \multirow{3}{*}{$\begin{array}{l}\text { Oil } \\
\text { Production } \\
\text { Value }\end{array}$} & \multirow{3}{*}{$\begin{array}{l}\text { Pearson } \\
\text { Correlation } \\
\text { Sig (2-tailed) } \\
\text { N }\end{array}$} & $899^{* *}$ & $901^{* *}$ & \multirow{3}{*}{21} \\
\hline & & 000 & 000 & \\
\hline & & 21 & 21 & \\
\hline
\end{tabular}

** Correlation is significant at the 001 level (2-tailed)

The above table demonstrated that there were factually critical connection among GDP and Oil cost in light of the fact that the pesteem were not exactly the basic alpha 0 05 Subsequently, the connection among GDP and Oil cost were firmly certain in light of the fact that the estimation of relationship coefficient equivalents to 0831 which is more prominent than the estimation of connection coefficient (l) 5 ) this implies if the oil cost builds, the GDP will increment also Besides, there were measurably huge connection among GDP and Oil creation esteem on the grounds that the p-esteem were not exactly the basic alpha $0 \quad 05$ Therefore, the connection among GDP and Oil creation esteem were unequivocally certain in light of the fact that the estimation of relationship coefficient equivalents to $0 \quad 901$ which is more noteworthy than the estimation of relationship coefficient $\left(\begin{array}{ll}0 & 5\end{array}\right)$ this implies if the oil creation esteem builds, the GDP will increment too

\section{CONCLUSION}

Economic development is one of the most significant wellsprings of financial change since it mirrors the network's capacity to increment profitable limit and ideal venture and furthermore supportability necessity remembers a broadened economy for the substance of stuns, progressively embraces innovation and head collection human 
cash, seriously can increase relative points of interest contrasted with the other In this manner, it works inside steady, stable monetary arrangements and financial turn of events Oil prices have been influenced by global emergencies, as oil is a key worldwide ware joining political, financial and international variables which is impact it There were measurably huge connection among GDP and Oil cost on the grounds that the pesteem was not exactly the regular alpha 005 Accordingly, the connection between genuine GDP and oil cost were firmly sure on the grounds that the estimation of relationship coefficient equivalents to 0831 which is more noteworthy than the estimation of connection coefficient $\left(\begin{array}{ll}0 & 5\end{array}\right)$ this implies if the oil cost builds, the genuine GDP will increment too Besides, there were measurably huge connections between genuine GDP and oil creation esteem in light of the fact that the pesteem was not exactly the normal alpha 005 Therefore, the connection between genuine GDP and Oil creation esteem were unequivocally sure in light of the fact that the estimation of relationship coefficient equivalents to 0901 which is more noteworthy than the estimation of relationship coefficient $\left(\begin{array}{ll}0 & 5\end{array}\right)$ this implies if the oil creation esteem builds, the genuine GDP will increment also.

\section{RECOMMENDATION}

- Encourage banks move to the market in order to help methodology headings Cash in giving credit and bank financing which requires by the case of authentic GDP and work should raise level of money related improvement which requires raising the money related significance of the country.

- The money related methodology makers should make the oil portion, the advancement train through the petrochemical adventures, notwithstanding misuse financial sparing to help other monetary part in this occasions oil value ascends on the planet markets .

- The government attempts to fortify participation and organization with OPEC to control gracefully of unrefined petroleum in the OPEC area with the of influencing worldwide raw petroleum costs.

- Take preferred position of fruitful encounters in all nations that have comparative assets so as to open foundations or specific schools or focuses in this field.

\section{REFERENCES}

[1] Aimer, N M M (2016) The effects of oil price volatility on the economic sectors of Libya International Journal of Business and Social Research, 6(12), 13-24

[2] Alley, I (2018) Oil price and USD-Naira exchange rate crash: Can economic diversification save the Naira? Energy Policy, 118, 245-256

[3] Al-Sasi, B O, Taylan, O , \& Demirbas, A (2017) The impact of oil price volatility on economic growth Energy Sources, Part B: Economics, Planning, and Policy, 12(10), 847-852

[4] Chen, X , Sun, X , \& Li, J (2020) How does economic policy uncertainty react to oil price shocks? A multi-scale perspective Applied Economics Letters, 27(3), 188-193

[5] Chen, X, Sun, X , \& Li, J (2020) How does economic policy uncertainty react to oil price shocks? A multi-scale perspective Applied Economics Letters, 27(3), 188-193

[6] Dudian, M , Mosora, M , Mosora, C , \& Birova, S (2017) Oil Price and Economic Resilience Romania's Case Sustainability, 9(2), 273

[7] Gazdar, K, Hassan, M K, Safa, M F , \& Grassa, R (2019) Oil price volatility, Islamic financial development and economic growth in Gulf Cooperation Council (GCC) countries Borsa Istanbul Review, 19(3), 197-206

[8] Jarrett, U, Mohaddes, K, \& Mohtadi, H (2019) Oil price volatility, financial institutions and economic growth Energy Policy, 126, 131-144

[9] Jianwei, E , Bao, Y , \& Ye, J (2017) Crude oil price analysis and forecasting based on variational mode decomposition and independent component analysis Physica A: Statistical Mechanics and its Applications, 484, 412-427

[10] Katırcioglu, S , Ozatac, N , \& Taspinar, N (2020) The role of oil prices, growth and inflation in bank profitability The Service Industries Journal, 40(7-8), 565-584

[11] Lee, C C , \& Lee, C C (2019) Oil price shocks and Chinese banking performance: Do country risks matter? Energy Economics, 77, 46-53

[12] Li, Q, Cheng, K , \& Yang, X (2017) Response pattern of stock returns to international oil price shocks: From the perspective of China's oil industrial chain Applied Energy, 185, 1821-1831

[13] Lin, B , \& Su, T (2020) Mapping the oil price-stock market nexus researches: A scientometric review International Review of Economics \& Finance, 67, 133-147

[14] Maji, I K, Saari, M Y , Habibullah, M S , \& Utit, C (2017) Measuring the economic impacts of recent oil price shocks on oil-dependent economy: evidence from Malaysia Policy Studies, 38(4), 375-391

[15] Mo, B , Chen, C , Nie, H , \& Jiang, Y (2019) Visiting effects of crude oil price on economic growth in BRICS countries: Fresh evidence from wavelet-based quantile-on-quantile tests Energy, 178, 234-251

[16] Nwanna, I O , \& Eyedayi, A M (2016) Impact of crude oil price volatility on economic growth in Nigeria (1980-

This article can be downloaded from here: www.ijaems.com 
2014) IOSR Journal of Business and Management (IOSRJBM), 18(6), 10-19

[17] Nyangarika, A , Mikhaylov, A , \& Richter, U (2019) Influence oil price towards economic indicators in Russia International Journal of Energy Economics and Policy, 1(6), 123-130

[18] Okere, K , \& Ndubuisi, P (2017) The role of stock market development on economic growth in OPEC countries: does oil Price movement matter? Fresh evidence from Nigeria Asian Journal of Economic Modelling, 5(2), 194207

[19] Rui, Z, Wang, X , Zhang, Z , Lu, J , Chen, G , Zhou, X , \& Patil, S (2018) A realistic and integrated model for evaluating oil sands development with steam assisted gravity drainage technology in Canada Applied Energy, 213, 76-91

[20] Shahbaz, M , Sarwar, S , Chen, W , \& Malik, M N (2017) Dynamics of electricity consumption, oil price and economic growth: Global perspective Energy Policy, 108, 256-270

[21] Strpić, K , Miličević, M ，\& Kurevija, T (2017) Development of Tight Oil Resources in USA: Profitability of Exploitation and Effect of Macroeconomic Indicators in Volatile Oil Price Environment Rudarsko-geološko-naftni zbornik, 32(3), 23-33

[22] Wen, F, Min, F , Zhang, Y J , \& Yang, C (2019) Crude oil price shocks, monetary policy, and China's economy International Journal of Finance \& Economics, 24(2), 812-827

[23] You, W , Guo, Y , Zhu, H , \& Tang, Y (2017) Oil price shocks, economic policy uncertainty and industry stock returns in China: Asymmetric effects with quantile regression Energy Economics, 68, 1-18

[24] Zhao, L T , Wang, Y, Guo, S Q, \& Zeng, G R (2018) A novel method based on numerical fitting for oil price trend forecasting Applied Energy, 220, 154-163 